\title{
Antioxidant defense system versus 8-hydroxy-2' -deoxyguanosine; a short look to recent findings
}

\author{
Shadi Rahimpour ${ }^{1}$, Ali Hasanpour Dehkordi ${ }^{*}$ \\ ${ }^{1}$ Department of Toxicology, Islamic Azad University, Shahreza, Iran \\ ${ }^{2}$ Social Determinants of Health Research Center/ Department of Medical-Surgical, Faculty of Nursing and Midwifery, Shahrekord \\ University of Medical Sciences, Shahrekord, Iran
}

\section{A R T I C L E I N F O}

\section{Article Type:}

Epidemiology and Prevention

\section{Article History:}

Received: 18 December 2017

Accepted: 10 April 2018

Published online: 21 May 2018

\section{Implication for health policy/practice/research/medical education:}

The impact of 8-hydroxy-2' -deoxyguanosine as an oxidative stress biomarker has been detected in many diseases, including bladder and prostate cancer, rheumatoid arthritis and renal disease.

Please cite this paper as: Rahimpour S, Hasanpour Dehkordi A. Antioxidant defense system versus 8-hydroxy-2' -deoxyguanosine; a short look to recent findings. J Renal Inj Prev. 2018;7(3):121-123. doi: 10.15171/jrip.2018.29.

Keywords: Free radicals, 8-hydroxy-2'-deoxyguanosine, Antioxidant defense system, 8-hydroxyguanine, Oxidative stress, Antioxidant system
$\mathrm{F}$ ree radicals are atoms or molecules that are constantly circulating in the body due to the presence of single electrons damaging the macromolecules of organisms such as lipids, proteins, carbohydrates and DNA. There is a system called "antioxidant defense system" in the body to prevent damages to free radicals. Normally, there is a balance between free radicals and this system in the body of a healthy person. However, when this balance is disturbed for any reason i.e. the number of free radicals is increased or the antioxidant system is weakened, a state called oxidative stress is created being involved in the development of hundreds of diseases $(1,2)$. Free radicals, in the DNA structure of the body cells, can oxidase purine and pyrimidine bases, produce fractures in one or two strands, create cross-bridges between DNA and proteins, and change deoxyribose (3). Free radicals are capable of exposing vital biomolecules such as DNA to an oxidative attack creating changes in the DNA structure. The most common organic DNA base being exposed to oxidative attack by the free radicals is the position 8 of guanine base. During the attack of the free radicals to the organic C8 guanine is changed into 8-hydroxy guanine (Figure 1) (4).

The use of 8-hydroxy-2' -deoxyguanosine (8-OHdG) as an oxidative stress biomarker has been studied in many diseases, including bladder and prostate cancer (6) rheumatoid arthritis (7) and renal disease. As a result of oxidative stress, cellular damage often arises due to changes in macromolecules, such as proteins, lipids, and DNA nucleic acids. Nuclear and mitochondrial DNA are usually the site of oxidative damage. Generally, radical hydroxyl has the ability to change the normal guanine and deoxyguanosine of the nucleus or mitochondria into an abnormal state of OH-dG-8 and 8-hydroxyguanine (8-OHGua) or 8-hydroxy-2'-deoxyguanosine 5'-triphosphate (8-OH-dGTP) (8). Causing damage to the DNA and oxidizing the organic base, the 8 -hydroxyguanine $(8-\mathrm{OH}$ Gua) is released from the DNA with the help of the human 8-oxoguanine DNA N-glycosylase 1 (hOGG1) enzyme

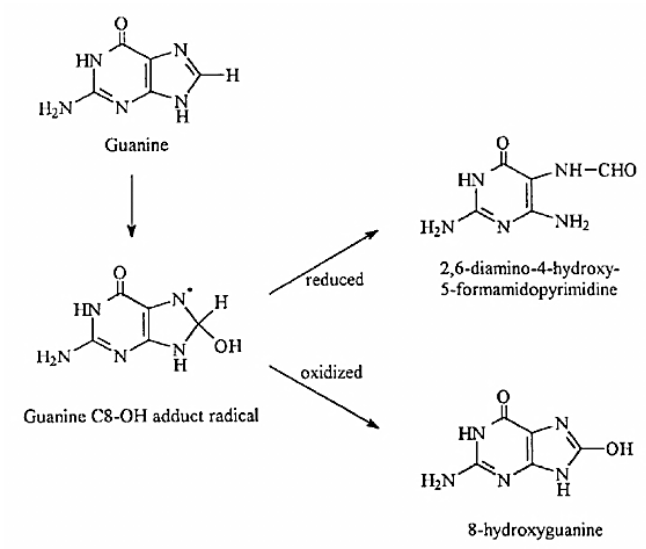

Figure 1. The products of damages of oxidative guanine through the attack of $\mathrm{OH}$ free radicals to $\mathrm{C} 8$ guanine (5). 
$(8,9)$. However, enzymes that cause $8-\mathrm{OH}-\mathrm{dG}$ are still unknown. 8-hydroxyguanosine 5'-triphosphate (8-OHGTP) is converted to the 8-hydroxy-2' -deoxyguanosine (8-OHdG) monophosphate via the MutT homolog 1 (MTH1) enzyme. Finally, its nucleotide form is created as 8-hydroxy-2' -deoxyguanosine (8-OHdG) (Figure 2). Additionally, 8-hydroxyguanine (8-OH-Gua) is obtained by free radical's attack on organic guanine base and DNA oxidation (Figure 3).

Form 8-hydroxy-2'-deoxyguanosine (8-OHdG) is associated with the physiological factors of individuals (age and gender), lifestyle (smoking, drinking and exercise), and diseases (cancer, diabetes and arthritis) (11). The results of the recent researches indicated the beneficial effects of regular exercise in reducing and preventing diseases associated with oxidative stress, which are due to strengthening the antioxidant system of the body in the course of regular, long-term and moderate exercise activity (12). Cigarette smoke is a powerful source of free radicals inducing oxidative stress in individuals (13). In addition 8-hydroxy-2' -deoxyguanosine (8-OHdG) is created by apoptotic cells obtained through oxidative stress. As a result, to study the oxidative damage to DNA, we measure the quantity of 8 -hydroxydeoxyguanosine (14). Various methods have developed for quantitative evaluation of urinary 8-OHdG concentrations, including gas chromatography-mass spectrometry [GC-MS], enzyme-linked immunosorbent assay (ELISA), liquid chromatography with mass spectrometry(LC-MS) (1519). LC-MS and high performance liquid chromatography

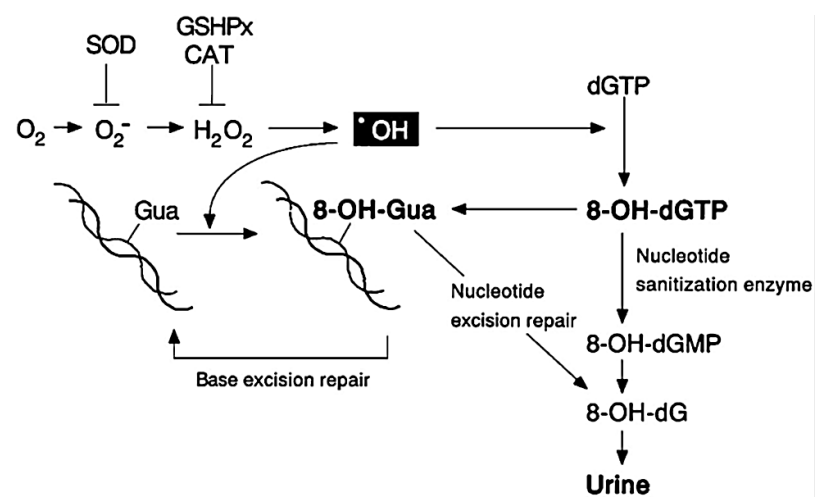

Figure 2. OhdG-8 urinary sources (10).

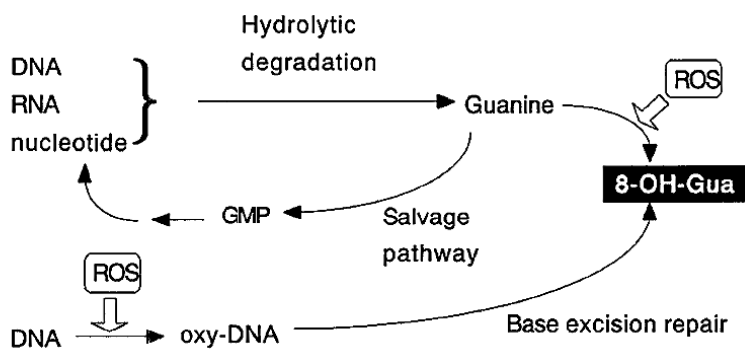

Figure 3. Urinary and serum $\mathrm{OH}-\mathrm{Gua}-8$ sources.
(HPLC) as the two methods are based on solid phase extraction (SPE) columns $(19,20)$.

Authors' contribution

SR and AHD contributed equally to the study.

Conflicts of interest

The authors declare no conflict of interest.

Ethical considerations

Ethical issues (including plagiarism, data fabrication, double publication) have been completely observed by the authors.

Funding/Support

None.

\section{References}

1. Small DM, Coombes JS, Bennett N, Johnson DW, Gobe GC. Oxidative stress, anti-oxidant therapies and chronic kidney disease. Nephrology (Carlton). 2012;17:311-21. doi: 10.1111/j.1440-1797.2012.01572.x.

2. Wang $\mathrm{CH}, \mathrm{Wu} \mathrm{SB}, \mathrm{Wu} \mathrm{YT}$, Wei YH. Oxidative stress response elicited by mitochondrial dysfunction: implication in the pathophysiology of aging. Exp Biol Med (Maywood). 2013;238:450-60. doi: 10.1177/1535370213493069.

3. Rehman A, Jenner A, Halliwell B. Gas chromatographymass spectrometry analysis of DNA: optimization of protocols for isolation and analysis of DNA from human blood. Methods Enzymol. 2000;319:401-17.

4. Cadet J, Wagner JR. DNA base damage by reactive oxygen species, oxidizing agents, and UV radiation. Cold Spring Harbor perspectives in biology. Cold Spring Harb Perspect Biol. 2013;5:a012559. doi: 10.1101/cshperspect.a012559.

5. Alam ZI, Jenner A, Daniel SE, Lees AJ, Cairns N, Marsden $\mathrm{CD}$, et al. Oxidative DNA Damage in the Parkinsonian Brain: An Apparent Selective Increase in 8-Hydroxyguanine Levels in Substantia Nigra. J Neurochem. 1997;69:1196203.

6. Chiou CC, Chang PY, Chan EC, Wu TL, Tsao KC, Wu JT. Urinary 8-hydroxydeoxyguanosine and its analogs as DNA marker of oxidative stress: development of an ELISA and measurement in both bladder and prostate cancers. Clin Chim Acta. 2003;334:87-94.

7. Rall LC, Roubenoff R, Meydani SN, Han SN, Meydani M. Urinary 8-hydroxy-2'-deoxyguanosine (8-OHdG) as a marker of oxidative stress in rheumatoid arthritis and aging: effect of progressive resistance training. J Nutr Biochem. 2000;11:581-4.

8. Nakano M, Kawanishi Y, Kamohara S, Uchida Y, Shiota M, Inatomi $\mathrm{Y}$, et al. Oxidative DNA damage (8-hydroxydeoxyguanosine) and body iron status: a study on 2507 healthy people. Free Radic Biol Med. 2003;35:82632 .

9. Li YS, Song MF, Kasai H, Kawai K. 8-hydroxyguanine in urine and serum as an oxidative stress marker: effects of diabetes and aging. J UOEH. 2013;35:119-27.

10. Kasai H, Kawai K, Li YS. Analysis of 8-OH-dG and 8-OHGua as biomarkers of oxidative stress. Genes Environ. 2008;30:33-40. doi: 10.3123/jemsge.30.33

11. Maeshima E, Liang XM, Otani H, Mune M, Yukawa S. Effect 
of environmental changes on oxidative deoxyribonucleic acid (DNA) damage in systemic lupus erythematosus. Arch Environ Health. 2002;57:425-8.

12. Powers SK, Deruisseau KC, Quindry J, Hamilton KL. Dietary antioxidants and exercise. J Sports Sci. 2004;22:8194.

13. Babizhayev MA, Yegorov YE. Smoking and health: association between telomere length and factors impacting on human disease, quality of life and life span in a large population-based cohort under the effect of smoking duration. Fundam Clin Pharmacol. 2011;25:425-42. doi: 10.1111/j.1472-8206.2010.00866.x.

14. Pater P, Seuntjens J, El Naqa I, Bernal MA. On the consistency of Monte Carlo track structure DNA damage simulations. Med Phys. 2014;41:121708. doi: 10.1118/1.4901555.

15. Alam ZI, Jenner A, Daniel SE, Lees AJ, Cairns N, Marsden $\mathrm{CD}$, et al. Oxidative DNA Damage in the Parkinsonian Brain: An Apparent Selective Increase in 8-Hydroxyguanine Levels in Substantia Nigra. J Neurochem. 1997;69:1196203.

16. Hosen MB, Islam MR, Begum F, Kabir Y, Howlader MZ. Oxidative stress induced sperm DNA damage, a possible reason for male infertility. Iran J Reprod Med. 2015;13:52532.

17. Rota C, Cristoni S, Trenti T, Cariani E. A serially coupled stationary phase method for the determination of urinary 8-oxo-7, 8-dihydro-2'-deoxyguanosine by liquid chromatography ion trap tandem mass spectrometry. Redox Biol. 2013;1:492-7. doi: 10.1016/j.redox.2013.10.001. eCollection 2013.

18. Zhang X, Hou H, Chen H, Liu Y, Wang A, Hu Q. A column-switching LC-MS/MS method for simultaneous quantification of biomarkers for 1, 3-butadiene exposure and oxidative damage in human urine. J Chromatogr B Analyt Technol Biomed Life Sci. 2015;1002:123-9. doi: 10.1016/j.jchromb.2015.08.012.

19. De Martinis BS, BIANCHI MD. Methodology for urinary 8-hydroxy-2'-deoxyguanosine analysis by HPLC with electrochemical detection. Pharmacol Res. 2002;46:129-31.

20. Inaba Y, Koide S, Yokoyama K, Karube I. Development of urinary 8-hydroxy-2'-deoxyguanosine (8-OHdG) measurement method combined with SPE. J Chromatogr Sci. 2011;49:303-9.

Copyright (c) 2018 The Author(s); Published by Nickan Research Institute. This is an open-access article distributed under the terms of the Creative Commons Attribution License (http://creativecommons.org/licenses/by/4.0), which permits unrestricted use, distribution, and reproduction in any medium, provided the original work is properly cited. 